ISSN: 2146-3042

DOI:

\title{
Şerefiyenin Raporlanmasına Yönelik IASB'nin Yaptığı İyileştirme Çalışmaları ve Mevcut Uygulamanın BIST 50 İşletmeleri Kapsamında Değerlendirilmesi *
}

\author{
Y1ldı̈ ÖZERHAN** \\ Banu SULTANOĞLU***
}

\section{ÖZET}

Uluslararası Muhasebe Standartları Kurulu, 2020 yılında, İşletme Birleşmeleri - Açıklamalar, Şerefiye ve Değer Düşüklüğü başlıklı Tartışma Metnini yayınlamıştır. Tartışma Metninde ele alınan konular, birleşmeye ilişkin bilgilerin açıklanması, şerefiyede değer düşüklüğü testinin etkinliği ve maliyeti, şerefiyenin itfasının yeniden uygulanıp uygulanmayacağı ve tanımlanabilir maddi olmayan duran varlıkların şerefiyeden ayrı olarak muhasebeleştirilmesidir. Bu çalışmada, Tartı̧̧ma Metninde ele alınan konular irdelenmiş, farklı bakış açıları gerekçeleriyle birlikte özetlenmiş ve ülkemizdeki işletmelerin bu konulara ilişkin mevcut durumunu ortaya koymak amacıyla BIST 50 endeksinde işlem gören işletmelerin finansal tablo dipnotlart incelenmiştir. Inceleme sonunda elde edilen bulgulara göre, şerefiyeyi raporlayan işletmelerin dipnot bilgilerinde, Standartta yer alan ilkelerin açıklandığı ve şerefiyenin değer düşüklüğ̈̈ testine tabi tutulduğu ancak büyük bir çoğunluğunun değer düşüklüğ̈̈ zararını raporlamadı̆̆ tespit edilmiştir.

Anahtar Kelimeler: İ̧sletme birleşmesi, şerefiye, değer düşüklüğ̈̈, geri kazanılabilir tutar

JEL Sinıflandırmasi: M41, M49.

\section{The Improvement Studies of IASB on The Reporting of Goodwill and The Current} Application of BIST 50 Companies Within This Framework

\section{ABSTRACT}

International Accounting Standards Board issued a Discussion Paper called Business Combinations Disclosures, Goodwill and Impairment in 2020. Disclosures about acquisitions, the effectiveness and cost of impairment test, reintroduction of the amortization and recognition of goodwill separately from identifiable intangible assets are considered to be the discussion points in the Paper. In this study, those discussion points are summarized by explaining the different point of views and in order to state the current applications of BIST 50 companies, their financial statement disclosures are examined. The results revealed that, the companies disclosed the goodwill within the principles stated in the Standard and also they conducted impairment tests, however it was found that, the majority did not recognize any impairment loss for goodwill.

Keywords: Business combinations, goodwill, impairment, recoverable amount.

Jel Classification: M41, M49.

\footnotetext{
* Bu makale, 23-25 Nisan 2021 tarihleri arasında gerçekleștirilen VI. Uluslararası Muhasebe ve Finans Sempozyumunda bildiri olarak sunulmuştur.

Makale Gönderim Tarihi: 13.05.2021, Makale Kabul Tarihi: 16.05.2021 , Makale Türü: Nitel Analiz

${ }^{* *}$ Prof. Dr., Ankara Hac1 Bayram Veli Üniversitesi, İktisadi ve İdari Bilimler Fakültesi, yildiz.ozerhan@hbv.edu.tr, https://orcid.org/0000-0002-1589-2692

*** Dr., Bilkent Üniversitesi, İşletme Fakültesi, sbanu@bilkent.edu.tr, https://orcid.org/0000-0003-0114-1553.
} 


\section{GíRiş}

Ekonomik alanda yaşanan gelişmeler ve küreselleşme ile birlikte, ülkeler arasındaki sınırlar ortadan kalkmış ve işletmeler arası birleşmeler gittikçe önem kazanmaya başlamıştır. 2020 yılı S\&P verilerine göre, birleşme ve satın almaların dünya genelindeki hacmi 2,8 trilyon Amerikan dolarına, Türkiye'de ise, yaklaşık 9 milyar Amerikan Dolarına ulaşmıştır (Deloitte Annual Turkish MA Review, 2020). Dünya genelinde borsada işlem gören tüm işletmelerin finansal tablolarında raporladığı şerefiye tutarı 4 trilyon Amerikan Dolarına ulaşmış ve bu tutar, aktif büyüklügünün \%3'ünü temsil etmektedir (Business CombinationsDisclosures, Goodwill and Impairment Discussion Paper (DP) - IN1).

Şerefiyenin finansal tablolardaki öneminin artması, ölçümü ve dipnot açıklamalarını da paydaşlar açısından önemli hale getirmiştir. Şerefiyenin raporlanmasına ilişkin ilkeler, Uluslararası Muhasebe Standartları Kurulu (IASB) tarafından gözden geçirilerek 2008 yılında yeniden yayınlanan IFRS 3 İşletme Birleşmeleri Standardında açıklanmaktadır. IFRS 3 yayınlandıktan ve uygulanmaya başlandıktan itibaren, standarda yönelik olarak paydaşlardan olumlu/olumsuz geri bildirimler alınmaya başlanmıştır. IASB, 2013 - 2015 yılları arasında, paydaşlardan gelen geri bildirimleri içeren "IFRS 3'ün Uygulama Sonrası Gözden Geçirilme Raporu”nu (PIR - Post-implementation Review of IFRS 3 Business Combinations) 2015 yılında yayınlamıştır. Bu rapor içeriğinde, yatırımcılar, diğer finansal tablo kullanıcıları, finansal tablo hazırlayıcıları, denetçiler ve düzenleyici kuruluşlardan alınan geri bildirimler ve konuyla ilgili yapılan akademik çalışmalara ilişkin bilgiler yer almaktadır. Yatırımcılardan gelen geri bildirimlerde üzerinde durulan hususlar; şerefiyenin sonraki dönemde raporlanması, değer düşüklügü testinin etkinliği, maddi olmayan duran varlıkların şerefiyeden ayrı olarak raporlanması, kontrol gücü olmayan payların ölçümü ve koşullu bedelin (transfer edilen bedele dahil edilen) sonraki dönemlerde muhasebeleştirilmesidir. Finansal tablo hazırlayıcıları, denetçiler ve düzenleyici kuruluşlardan alınan geri bildirimlerde ise, işletme tanımı, gerçeğe uygun değerin ölçümü ve şerefiyede değer düşüklüğü testine ilişkin uygulamada karşılaşılan sorunlara odaklanılmıştır. Paydaşların üzerinde durduğu hususların tekrar değerlendirilmesi ve tespit edilen sorunların gözden geçirilmesi amacıyla, 2015 yılında IASB tarafından "Şerefiye ve Değer Düşüklüğü Araştırma Projesi" (Goodwill and Impairment Project) başlatılmıştır. Bu projenin amacı, işletmelerin makul bir maliyetle, işletme birleşmeleri hakkında yatırımcılara faydalı bilgiler sunup sunmadığını belirlemektir. Yatırımcılardan kasıt, Kavramsal Çerçevede açıklandığı gibi, mevcut ve potansiyel yatırımcılar, borç verenler ve kredi veren diğer taraflardır (DP - IN3). IASB, Proje kapsamında, 2020 yılında "İşletme Birleşmeleri - Açıklamalar, Şerefiye ve Değer Düşüklüğü” başlıklı Tartışma Metnini (Business Combinations_-Disclosures, Goodwill and Impairment) yayınlamış ve paydaşların görüşüne açmıştır.

$\mathrm{Bu}$ çalışmanın amacı, IASB'nin yayınladığı Tartışma Metninde ele alınan konuları irdelemek ve şerefiyenin raporlanmasına yönelik uygulamaları BIST 50 endeksinde işlem gören işletmeler açısından incelemektir. Bu kapsamda, işletmelerin 2020 yılsonuna ait finansal tabloları gözden geçirilerek, şerefiyenin sonraki dönemlerde değer düşüklügü açısından nasıl test edildiği, kullanılan varsayımların neler olduğu ve yatırımcılara hangi bilgilerin sunulduğuna ilişsin bulgular değerlendirilmiştir. 


\section{2. İŞLETME BİRLEŞMELERININ MUHASEBELEŞTİRILMESI - TARIHHSEL SÜREÇ}

1993 - IAS 22 İşletme birleşmelerinin muhasebeleştirilmesine ilişkin olarak Uluslararası Muhasebe Standartları Kurulu (IASB) tarafindan yayınlanan ilk standart, 1983 tarihli “IAS 22 - İşletme Birleşmelerinin Muhasebeleştirilmesi”dir. Söz konusu standart, 1993 yılında gözden geçirilmiş ve "İşletme Birleşmeleri" adı altında yeniden yayınlanarak, uygulamaya konmuştur. Standartta, işletme birleşmelerinin muhasebeleştirilmesinde iki yönteme yer verilmiştir. Bunlar, çıkarların birleştirilmesi yöntemi ve satın alma yöntemidir. Satın alma yönteminin uygulanmasında, şerefiye ortaya çıkmakta ve şerefiye yirmi yılı aşmamak kaydıyla faydalı ömrü boyunca doğrusal amortisman yöntemine göre itfaya tabi tutulmaktadır. Nadir durumlarda, şerefiyenin faydalı ömrünün yirmi yılın üzerinde tahmin edilmesi halinde, IAS 36 "Varlıklarda Değer Düşüklüğü" Standardına göre, değer düşüklügüne ilişkin gösterge olmasa bile, yıllık geri kazanılabilir tutarın hesaplanması gerekmektedir. Şerefiyenin itfa edilmesi, zorunlu bir ilke olarak karşımıza çıkmaktadır.

2004 - IFRS 3 IAS 22'ye gelen eleştirileri dikkate alarak, yeni bir standart yayınlama yönünde çalışmalara başlayan IASB, 2004 yılında IAS 22'nin yerini almak üzere, "IFRS 3 İşletme Birleşmeleri” Standardını yayınlamış ve IAS 22'yi yürürlükten kaldırmıştır. IFRS 3 'te, işletme birleşmelerinin muhasebeleştirilmesinde, tek bir yönteme; satın alma yöntemine yer verilmiştir. Şerefiyede itfa uygulamasına son verilmiş ve şerefiyenin IAS 36 çerçevesinde, yı1lık düzenli olarak değer düşüklüğü testine tabi tutulması öngörülmüştür. IFRS 3, 2008 yılında, gözden geçirilerek, tekrar yayınlanmıştır.

2013-2015 - IFRS 3’ün Uygulama Sonrası Gözden Geçirilmesi (PIR - Postimplementation Review of IFRS 3) IASB, 2013 - 2015 y1lları arasında, IFRS 3 Standardının uygulanmaya başlandıktan sonra, PIR çerçevesinde gözden geçirme faaliyetlerini yürütmüş ve paydaşlardan gelen geri bildirimleri 2015 yılında bir rapor halinde yayınlamıştır. Bu rapor içeriğinde, yatırımcı ve diğer finansal tablo kullanıcıları, finansal tablo hazırlayıcıları, denetçiler ve düzenleyici kuruluşlardan alınan geri bildirimler ve akademik çalışmalar yer almaktadır. Yatırımcılardan gelen geri bildirimlerde üzerinde durulan hususlar; şerefiyenin izleyen dönemde muhasebeleştirilmesi, maddi olmayan duran varlıkların şerefiyeden ayrı olarak raporlanması, kontrol gücü olmayan payların ölçümü ve koşullu bedelin (transfer edilen bedele dahil edilen) sonraki dönemde muhasebeleştirilmesidir. Finansal tablo hazırlayıcıları, denetçiler ve düzenleyici kuruluşlardan alınan geri bildirimlerde ise, işletme tanımı, gerçeğe uygun değerin ölçümü ve şerefiyede değer düşüklüğü testine ilişkin uygulamada karşılaşılan sorunlara odaklanılmıştır. Söz konusu hususlara çözüm bulunması amacıyla 2015 yılında "Şerefiye ve Değer Düşüklüğü Araştırma Projesi” başlatılmış ve bu çerçevede 2 Mart 2020’de "İşletme Birleşmeleri - Açıklamalar, Şerefiye ve Değer Düşüklügü Tartışma Metni” yayınlanmıştır.

\section{3. ŞEREFIYE}

İşletme birleşmesinde elde edilen şerefiye, bireysel olarak tespit edilmeleri ve ayrı olarak muhasebeleştirilmeleri imkânı olmayan varlıklardan beklenen gelecekteki ekonomik yararlar için, edinen işletme tarafından yapılan ödemeyi temsil eden bir varlıktır (TMS 36, md.81). Şerefiye, transfer edilen bedelin edinilen işletmenin net tanımlanabilir varlıklarının gerçeğe uygun değerini aşan kısmıdır. Edinen işletmenin daha yüksek bir bedel ödemesinin 
nedeni, birleşmenin yaratacağı sinerjiden dolayı, gelecekte ekonomik yarar sağlayacağı beklentisinin olmasıdır.

IFRS 3 İşletme Birleşmeleri Standardına göre, şerefiye aşağıdaki şekilde hesaplanmaktadir:

Şerefiye $=$ Transfer Edilen Bedel + Kontrol Gücü Olmayan Paylar + Daha Önce EIde

Tutulan Payların Gerçeğe Uygun Değeri - Edinilen İşletmenin Net Tanımlanabilir

Varlıklarının Gerçeğe Uygun Değeri

Şerefiye, yukarıdaki formüle göre hesaplandığında, pazarlıklı satın alma sonucu, negatif bir tutar olarak da ortaya çıkabilmektedir. Ucuza satın alma kazancı olarak ifade edilen bu tutar, birleşme tarihinde kar veya zararda muhasebeleştirilir.

İşletme birleşmesi sonucunda ortaya çıkan şerefiye, ayrı olarak tanımlanamayan, diğer varlıklardan veya varlık gruplarından bağımsız nakit akışları yaratmayan bir varlık unsurudur ve genellikle birden fazla nakit yaratan birimin nakit akışına katkıda bulunmaktadır.

Şerefiye, finansal tablolarda ayrı bir başlık altında raporlanmaktadır. IFRS 3 ve IAS 36'ya göre, şerefiye, tek başına işletmeye nakit akışı sağlayan bir varlık olmadığı, gelecekte işletmeye ne kadar yarar sağlayacağ 1 tahmin edilemediği için, sonraki dönemlerde ölçümünde sadece y1llık düzenli bir şekilde değer düşüklüğü testine tabi tutulmakta ve itfa edilmemektedir. Şerefiyenin sonraki dönemlerde ölçümüne yönelik olarak teoride de, iki farklı görüş bulunmakta olup, 20.yy'ın başlarından itibaren bu konu tartışılmaya başlanmıştır. L.R. Dicksee ve Tillyard, 1906 ve H.R. Hatfield, 1909 (içinde Aleksey ve diğerleri, 2018), şerefiyenin sınırlı bir yararlı ömre sahip olduğunu ve itfa edilerek kayıtlardan çıkarılması gerektiğini savunmuşlardır. Bu yöntem, 1930-40’lı y1lların başından itibaren birçok ülkenin muhasebe standartlarında geçerli bir yöntem olarak yer almıştır. Bu dönemde tartışılan ve ilk olarak Charpentier (1906) tarafından gündeme getirilen bir diğer görüş ise, şerefiyenin değer düşüklüğü zararı düşüldükten sonraki tutarı üzerinden raporlanması yönündedir. Şerefiyenin değer düşüklüğü testine tabi tutularak finansal tablolarda raporlanması, finansal tabloların güvenilirliliği açısından literatürde de, üzerinde uzun süre tartışılan bir konu olmaya devam etmektedir (Beatty ve Weber, 2006; Gu ve Lev, 2011; Ramanna ve Watts, 2012).

Değer düşüklüğü testi açısından şerefiye, nakit yaratan birimlere dağıtılır. Şerefiyenin dağıtıldığı nakit yaratan birim her yıl aynı zamanda göstergelerden bağımsız olarak değer düşüklüğü açısından test edilir. Değer düşüklüğü testi, geri kazanılabilir tutarın hesaplanarak, defter değeri ile karşılaştırılması suretiyle yapılır (IAS 36, md.10). Geri kazanılabilir tutar, bir varlığın veya nakit yaratan birimin, satış maliyetleri düşülmüş gerçeğe uygun değeri ile kullanım değerinden yüksek olanıdır (IAS 36, md.6). Satış maliyeti düşülmüş gerçeğe uygun değer, piyasa katılımcıları arasında ölçüm tarihinde olağan bir işlemde, bir varlığın satışından elde edilecek tutardan satış maliyetlerinin düşülmesi suretiyle bulunan değerdir. Aktif bir piyasanın olmadığı durumda, gerçeğe uygun değerin tespitinde yaygın olarak kullanılan üç değerleme yöntemi; piyasa yaklaşımı, maliyet yaklaşımı ve gelir yaklaşımıdır. Piyasa yaklaşımı, özdeş veya karşılaştırılabilir (başka bir ifadeyle benzer) olan varlıklara, borçlara ya da varlıklardan ve borçlardan oluşan bir gruba (örneğin iş) ilişkin piyasa işlemleri sonucu oluşan fiyatları ve diğer ilgili bilgileri kullanır. (TFRS 13, Ek-B5). Maliyet yaklaşımı, bir 
varlığın hizmet kapasitesini yenilemek için gerekli olan cari tutarı yansıtır (genellikle cari yenileme maliyeti olarak anılır) (TFRS 13, Ek-B8). Gelir yaklaşımı ise, gelecekteki tutarları (örneğin, nakit akışları veya gelir ve giderleri) tek bir cari (başka bir ifadeyle, iskonto edilmiş) tutara dönüştüren yöntemdir. Gelir yaklaşımı kullanıldığında, gerçeğe uygun değer ölçümü gelecekteki tutarlara ilişkin cari piyasa beklentilerini yansıtır (TFRS 13, Ek-B10). Kullanım değeri, bir varlık veya nakit yaratan birimden elde edilmesi beklenen gelecekteki nakit akışlarının bugünkü değeridir.

Şerefiyede ortaya çıkan değer düşüklüğünün sonraki dönemlerde iptali de söz konusu değildir. Şerefiyenin bu şekilde raporlanması, yatırımcıların, işletme yönetiminin birleşme ile ilgili olarak almış olduğu kararın isabetli bir karar olup olmadığını değerlendirebilmelerine imkân tanımaktadır.

\section{IFRS 3 İŞLETME BİRLEŞMELERİ - AÇIKLAMALAR, ŞEREFIYYE VE DEĞER DÜŞÜKLÜĞÜ TARTIŞMA METNINDE PAYDAŞLARIN GÖRÜŞÜNE SUNULAN ÖNEMLİ KONULAR}

2020 yılında yayınlanan Tartışma Metninde, IASB'nin ön görüşlerini paylaştı̆̆ 1 ve paydaşlardan geri bildirimlerini istediği konu başlıkları aşağıdaki gibidir:

- Birleşmeye ilişkin bilgilerin dipnotlarda açıklanması

- $\quad$ Şerefiyede değer düşüklügü testi - etkinliği ve maliyeti

- Şerefiyede itfanın yeniden uygulanıp uygulanmayacağının değerlendirilmesi

- Maddi olmayan duran varlıkların şerefiyeden ayrı olarak muhasebeleştirilmesi

\subsection{Birleşmeye İlişkin Bilgilerin Dipnotlarda Açıklanması}

IFRS 3 uygulanmaya başladıktan sonra, kurula gelen geri bildirimlerde, yatırımcıların elde etme bedelinin (transfer edilen bedel) makul bir fiyat olup olmadığ başarılı olup olmadığını anlamak istedikleri, ancak bazı işletmelerin IFRS 3 'teki açıklamalara ilişkin ilkelere rağmen, yatırımcılara birleşmeyi tam olarak anlamalarını sağlayıcı, yeterli düzeyde faydalı bilgi sunmadıkları ifade edilmektedir (DP - IN18). IFRS 3'te, raporlama döneminde gerçekleşen işletme birleşmelerine ilişkin olarak finansal tablo kullanıcılarına faydalı olacak açıklamaların yapılması istenmektedir. Buna göre, finansal tablo kullanıcılarının edinen işletmenin dönem içinde gerçekleşen veya raporlama tarihinden sonra, ancak finansal tablolar onaylanmadan önce gerçekleşen birleşme işlemlerinin niteliğini ve söz konusu birleşme işlemlerinin finansal etkilerini değerlendirebilmelerini sağlayan bilgileri dipnotlarında açıklaması gerekmektedir (IFRS 3, Md. 59). Edinen işletmenin, raporlama döneminde meydana gelen işletme birleşmelerine ilişkin olarak aşağıdaki bilgileri sunması istenmektedir (IFRS 3, B64):

$\checkmark \quad$ edinilen işletmenin unvanı ve tanımı, birleşme tarihi, edinilen işletmedeki oy hakkına sahip özkaynak payı yüzdesi,

$\checkmark \quad$ işletme birleşmesinin ana nedenleri ve edinen işletmenin edinilen işletmenin kontrolünü nasıl elde ettiği,

$\checkmark \quad$ şerefiyenin ortaya çıkmasına neden olan faktörler; örneğin; edinilen ve edinen işletmenin faaliyetlerinin birleştirilmesinden ortaya çıkması beklenen sinerjiler, ayrı muhasebeleştirilmeyen maddi olmayan duran varlıklar veya diğer faktörler, 
$\checkmark \quad$ transfer edilen bedelin birleşme tarihindeki toplam gerçeğe uygun değeri,

$\checkmark \quad$ koşullu bedel düzenlemeleri, tazminat varlıkları, edinilen alacakların gerçeğe uygun değeri, edinilen varlık ve üstlenilen borç sınıfına ilişsin birleşme tarihi itibari ile muhasebeleştirilen tutarlar ve koşullu borçlara ilişkin açıklamalar,

$\checkmark \quad$ vergisel nedenlerle indirilebilmesi beklenen şerefiyenin toplam tutarı,

$\checkmark \quad$ satın alma maliyetleri,

$\checkmark \quad$ pazarlıklı bir satın alma sonucu ortaya çıkan kazancın finansal tablolarda hangi kalemde muhasebeleştirildiği ve neden kazançla sonuçlandığı, kontrol gücü olmayan payların olması halinde, bu payların hangi yönteme göre ölçüldüğü (gerçeğe uygun değer veya oransal pay) ve işletme birleşmesinin aşamalı olarak gerçekleşmesi halinde, birleşme tarihinden önce elde tutulan payların birleşme tarihindeki gerçeğe uygun değeri ve ortaya çıkan kazanç veya zararın kapsamlı gelir tablosunda hangi kalemde muhasebeleştirildiğine ilişkin açıklamalar,

$\checkmark \quad$ edinilen işletmenin birleşme öncesi ve birleşme tarihinden sonraki cari raporlama dönemine ilişkin hasılat ve kar veya zarar tutarı

Yukarıda da açıklandığı gibi, IFRS 3'te birleşmenin gerçekleştiği dönemde sunulan finansal tabloların dipnotlarında birçok bilginin kapsamlı olarak açıklanması istenmektedir. Ancak, paydaşlardan Kurul'a gelen geri bildirimlerde, bu bilgilerin yatırımcıların birleşmenin neden yapıldığını anlamalarını sağlayacak düzeyde olmadığı, özellikle birleşmenin sonraki performansı hakkında IFRS 3'te bir açıklama zorunluluğu bulunmadığı için, yeterli bilginin sunulmadığı ve bu nedenle yatırımcıların yeterince bilgilendirilmedikleri tespitine yer verilmiştir. $\mathrm{Bu}$ tespitler çerçevesinde, Kurul ön görüş olarak, birleşmeye ilişkin finansal raporlarda yapılacak açıklamaların aşağıdaki bilgileri içermesi gerektiğine karar vermiştir. (DP- IN20):

a) Yönetimin ${ }^{1}$ birleşme amac1: IFRS 3, B64(d) maddesinde işletme yönetiminden birleşmenin nedenlerinin açıklanması istenmekte, ancak sunulan bu bilgiler yatırımcıların birleşmenin sonraki performansı hakkında yeterince bilgi sahibi olmalarına imkan tanımamaktadır. $\mathrm{Bu}$ eksikliği gidermek üzere, açıklamalar kısmına birleşme tarihinde yönetimin birleşme amacı ve stratejik gerçekliği hakkında yatırımcılara bilgi sunulması önerilmektedir.

b) Yönetimin birleşmenin amacına ulaşılıp ulaşılmadığını izlemekte kullanacağı ölçütler: Bu bilgi, yönetimin birleşme amacına ulaşılıp ulaşılmadığını nasıl izlediği ve ölçtüğüne dayalı olmalıdır. Kurul, amacın ölçümüne yönelik kendisi bir ölçüt geliştirmemiş ve "IFRS 8 Bölümsel Raporlama" standardındaki yaklaşıma benzer bir yaklaşımı benimsemiştir. Söz konusu ölçütler, sinerji tutarı, karın ölçümü, özkaynak karlılık oranı gibi finansal göstergelerin yanı sıra finansal olmayan bilgileri de içermektedir.

c) $\mathrm{Bu}$ ölçütler kullanılarak, sonraki raporlama dönemlerinde yönetimin birleşme amacına hangi seviyede ulaştığı veya ulaşamadığı,

d) IFRS 3'teki açıklamaları daha da iyileştirmek için sunulması gereken diğer bilgiler

\footnotetext{
1 Tartışma metninde, yönetim kavramı, "İşletmenin faaliyetlere ilişkin karar almaya yetkili mercii (the chief operating decision maker's (CODM’s) anlamında kullanılmaktadır. "Işsletmenin faaliyetlere ilişkin karar almaya yetkili mercii” terimi ile, belirli bir unvanı olan bir yönetici yerine, bir işlev belirtilmektedir. Bu işlev, bir işletmenin işletme bölümlerine kaynak tahsisi ve bu bölümlerin performansının değerlendirilmesidir. Genellikle, bir işletmede işletmenin faaliyetlere ilişkin karar almaya yetkili mercii, icra kurulu başkanı (CEO) veya işletmenin günlük işlerini yürütmekle sorumlu yönetici (COO) TFRS 83 olabilir ancak; örneğin, işletmenin faaliyetlere ilişkin karar almaya yetkili mercii yürütmeden sorumlu yöneticiler veya diğer kişilerden oluşan bir grup olabilir (IFRS 8: 7).
} 
Kurul'un önerdiği birleşmeye ilişkin dipnot açıklamalarının yapılması halinde, aşağıdaki Tablo 1'de gösterilen bilgilerin yatırımcılara sunulmuş olacağı kabul edilmektedir:

Tablo 1. IASB’nin Önerdiği Açıklamaların Yatırımcıya Sağlayacağı Bilgiler

\begin{tabular}{|l|c|c|}
\hline Açıklamalar & \multicolumn{2}{|c|}{ Yatırımcıya Sağlanacak Bilgiler } \\
\hline & $\begin{array}{c}\text { Birleşmeden Sağlanan } \\
\text { Fayda }\end{array}$ & $\begin{array}{c}\text { Birleşme Sonrası } \\
\text { Performans }\end{array}$ \\
\hline Stratejik Gerçeklik & $\checkmark$ & $*$ \\
\hline Yönetimin Birleşme Amacı & $\checkmark$ & $\checkmark$ \\
\hline $\begin{array}{l}\text { Yönetimin Birleşmenin Amacına Ulaşılıp Ulaşılmadığını } \\
\text { Izlemekte Kullanacağı Ölçütler }\end{array}$ & $\checkmark$ & $\checkmark$ \\
\hline Amaçlara Ulaşılıp Ulaşıılmadığı & & \\
\hline Beklenen Sinerji & $\checkmark$ & \\
\hline Finansal ve Çalışanlara Sağlanan Fayda Yükümlülükleri & $\checkmark$ & $\checkmark$ \\
\hline Edinilen İşletmenin Katkısı & & \\
\hline
\end{tabular}

Kaynak: IFRS Discussion Paper DP/2020/1

* yönetimin birleşme amacına yönelik yapacağı açıklamalar, birleşme sonrası performansa yönelik olarak doğrudan bilgi sağlamayacak olsa da, diğer açıklamaları anlamaya yardımcı olacaktır.

\section{2. Şerefiyede Değer Düşüklüğü Testi - Etkinliği ve Maliyeti}

IAS 36 Varlıklarda Değer Düşüklüğü Standardına göre, işletme birleşmeleri sonucunda ortaya çıkan şerefiye, değer düşüklüğü tespiti açısından, ait olduğu nakit yaratan birimin bir parçası olarak yılda en az bir kez teste tabi tutulmaktadır (TMS 36, md.10). Ancak bazı paydaşlardan kurula gelen geri bildirimlerde, şerefiyede ortaya çıkan değer düşüklüğü zararının, bu zararlara neden olan olayların üzerinden uzun bir zaman geçtikten sonra, çok geç raporlandığı ve bundan dolayı da şerefiyede değer düşüklüğü testinin etkin olmadığı ifade edilmektedir. Diğer taraftan, paydaşlar, şerefiyeye ilişkin ortaya çıkan değer düşüklüğü zararının geç raporlanmış olsa dahi, yatırımcıların konuya ilişkin önceki değerlendirmelerini teyit ettiğini, bazı durumlarda ise, yatırımcıların daha önce tanımlamadıkları değer düşüklüğü zararlarının değer düşüklüğü testi yapılarak ortaya çıkarıldığını savunarak, şerefiyede değer düşüklüğü zararının raporlanmasının finansal tablo kullanıcılarına faydalı bilgi sunduğunu belirtmişlerdir. Paydaşlar, değer düşüklüğü testinin daha etkin hale getirilmesi gerektiğini, bunun da zararın zamanında muhasebeleştirildiği takdirde sağlanabileceğini ifade etmektedirler. Glaum, Landsman ve Wyrwa (2018) tarafindan şerefiyenin değer düşüklüğü testini etkileyen değişkenlerin incelenmesine yönelik 21 ülke için yapılan araştırmada, kural bazlı ülkelerde zamanında sunum eğiliminin daha yüksek olduğu, bu sonucun ortaya çıkmasında yaptırımların önemli bir rol oynadığı tespit edilmiştir.

Şerefiyede değer düşüklüğü zararının gecikmeli raporlanması ve buna bağlı olarak etkinliğinin sorgulanmasına neden olan unsurlar şöyle açıklanmaktadır (DP - IN25-26)

a) Nakit akış tahminlerinin işletme yönetimi tarafindan iyimser yapılabilmesi: bu konuyla ilgili olarak yapılan akademik araştırmalar, bazı işletmelerin değer düşüklügü testi yaparken, kendi yararlarına olacak şekilde iyimser yargıda bulunduklarını göstermektedir (PIR, 34-35). Kurulun görüşüne göre, nakit akışlarının oldukça iyimser tahminine ilişkin olarak standartlarda herhangi bir düzenleme ve değişiklik yapılamayacağı, bu konunun 
denetçiler ve düzenleyici kuruluşlar tarafindan en iyi cevaplanması gereken bir konu olduğu açıklanmaktadır.

b) Şerefiyenin diğer varlıklardan veya varlık gruplarından bă̆ımsız nakit akışları yaratamaması ve bağımsız olarak ölçülemememesinden dolayı değer düşüklüğ̈̈ zararından korunabilmesi (shielding): Tartışma Metninde söz konusu korunmanın headroom olarak tanımlanan durumdan kaynaklandığı ifade edilmektedir. Headroom, nakit yaratan birimin geri kazanılabilir tutarının defter değerini aşan kısmı olarak tanımlanmaktadır (DP - 3.31). Bu olumlu farka neden olan unsurlar ise, işletme içi yaratılan şerefiye, varlık ve borçların defter değeri ve geri kazanılabilir tutarları arasındaki kayda alınmamış farklar ve finansal tablolarda raporlanmayan varlık ve yükümlülükler olarak açıklanmaktadır (DP - 1.9).

Yukarıda açıklanan nedenlerden dolayı, Kurul, IAS 36'da açıklanan şerefiyede değer düşüklüğü testi yaklaşımın etkinliğinin makul bir maliyetle, önemli ölçüde iyileştirilemeyeceği sonucuna varmıştır. Kurul, şerefiyede değer düşüklüğü testinin etkinliğinin arttırılması amacıyla, bu Tartışma Metninin “Açıklamalar Bölümü”nde yer alan "birleşmenin sonraki dönemlerdeki performansına ilişkin bilgilerin", sunulmasının gerekli olduğu görüşünü savunmuştur.

Şerefiyede değer düşüklüğü etkinliğinin arttırılması için, Kurulun bir diğer görüşü, işletmelerin finansal tablolarında şerefiye hariç özkaynak tutarını sunmalarıdır. Bu iyileştirilmiş şeffaf sunum biçimi ile yatırımcıların işletmenin finansal durumunu anlamalarını kolaylaştıracağı beklenmektedir. Kurul, bu şeffaf sunum biçiminin, değer düşüklüğü testinde şerefiyenin doğrudan test edilemediği ve şerefiyenin diğer varlıklardan farklı olmasından dolayı (ayrı olarak satılamadığı veya doğrudan ölçülemediği için) yatırımcılar için önemli olduğunu düşünmektedir (DP - IN41). Şerefiyenin bağımsız olarak ölçülememesi, şirket tasfiyesi sırasında diğer birçok varlığa göre nakde dönüştürülmesinin zorluğu, değer düşüklüğü testi için nakit yaratan birim gruplarına dağıtılması gibi nedenlerden dolayı bulunduğu hesap grubundan farklı nitelikte bir hesaptır (DP - 3.107). Bu nedenle, IAS 1 Finansal Tabloların Sunuluşu Standardına göre, şerefiyenin finansal durum tablosunda ayrı bir başlıkta sunulması öngörülmüş ve 2019 yılında yayınlanan "Genel Sunum ve Açıklamalara İlişkin Taslak Metin”de benzer yaklaşım benimsenmiştir.

Diğer taraftan, Kurul, Tartışma Metninde, özkaynakların sunumunda da, şerefiye hariç tutarın ayrıca gösterilmesine yönelik bir öneri geliştirmiş ve paydaşların görüşüne sunmuştur. Şerefiye hariç toplam özkaynak tutarının sunulması, şerefiyenin etkisi hakkında daha fazla şeffaflık sağlayacak ve böylece yatırımcıların bir şirketin finansal durumunu daha iyi anlamasına katkıda bulunacaktır (DP - 3.109). Diğer taraftan, şerefiyenin bir ara toplam olarak özkaynak grubunun içinde sunumunun mümkün olmaması; diğer bir deyişle finansal tabloların düzenini bozucu nitelikte olması ve yasal düzenlemelere göre, özkaynak kalemlerinin belirlenmiş olması nedeniyle, finansal durum tablosunun özkaynak bölümünde ara toplam olarak değil, toplam kaynakların altında aşağıda gösterildiği şekilde sunulması uygun görülmektedir (DP - 3.111-112). 


\section{Finansal Durum Tablosu}

$\begin{array}{lcc}\text { Dönen Varlıklar } & & 10.000 \\ \text { Duran Varlıklar } & \\ \text { - Maddi Duran Varlıklar } & 15.000 & 20.000 \\ \text { - Şerefiye } & 5.000 & \\ \text { TOPLAM VARLIKLAR } & & \mathbf{3 0 . 0 0 0} \\ \text { Kısa Vadeli Yükümlülükler } & 3.000 \\ \text { Uzun Vadeli Yükümlülükler } & 15.000 \\ \text { Özkaynaklar } & 12.000 \\ \text { TOPLAM KAYNAKLAR } & \mathbf{3 0 . 0 0 0} \\ \text { Şerefiye Hariç Özkaynaklar } & \mathbf{7 . 0 0 0}\end{array}$

Kaynak: Tartışma Metni, Ekler Bölümündeki Örnek Sunumdan Uyarlanmıştır

Kurulu'un Tartışma Metninde, değer düşüklüğü testinin maliyetine yönelik görüşü ise, şerefiyeyi içeren nakit yaratan birimler için yıllık niceliksel değer düşüklüğü testi yapma zorunluluğunun ortadan kaldırılması gerektiği yönündedir. İşletmelerin, değer düşüklüğü zararının ortaya çıktığına dair bir gösterge olmadıkça nicel bir test yapma zorunluluğu bulunmamalı, buna karşıllk her raporlama döneminin sonunda böyle bir gösterge olup olmadığını değerlendirmelerinin yeterli olacağı ifade edilmektedir. Bu uygulama şerefiyede değer düşüklüğü testinin maliyetini azaltacaktır (DP - IN42).

\section{3.Şerefiyede İtfanın Yeniden Uygulanıp Uygulanmayacağının Değerlendirilmesi}

Tartışma Metninde ele alınan konulardan bir diğeri, şerefiyede itfanın yeniden uygulamaya konup konmamasına ilişkin yapılan tartışmalardır. Şerefiyede itfa uygulaması, şerefiyenin defter değerini azaltmak ve işletmeleri değer düşüklüğü testi baskısından kurtarmak için basit bir yol olarak görülmekte ve değer düşüklüğü testinin doğasında olan sınırlamalar nedeniyle şerefiyenin defter değerinin yüksek gösterildiğine inanan paydaşların endişelerinin giderilmesine yardımcı olabilmektedir. (DP - IN32) Ancak, Kurul'un görüşü, itfanın yeniden uygulamaya konmaması yönündedir. Bu konuya ilişkin olarak, Kurul üyeleri tarafından dile getirilen lehte ve aleyhte görüşler aşağıda açıklanmaktadır (DP - IN 34)

Şerefiyede itfanın yeniden uygulamaya konmasını savunan Kurul üyeleri aşağıdaki görüşleri öne sürmektedir:

a) Şerefiyede değer düşüklüğü zararının zamanında raporlanmasına ilişkin olarak etkili bir değer düşüklüğü testi tasarlamanın uygulanabilir olduğu kanıtlanmamıştır. Şerefiyenin itfası, IFRS 3'e ilişkin alınan geri bildirimlerde değer düşüklüğü zararının zamanında raporlanmadığı sorununa da bir cevap niteliğinde olacaktır.

b)Dünya genelinde işletme birleşmelerinin hacminin artması, dolayısıyla finansal tablolarda raporlanan şerefiye tutarının artış göstermesi nedeniyle, finansal tabloların doğru bir şekilde sunumunu sağlamak için itfa uygulamasının yeniden getirilmesinin yararlı olacağ savunulmaktadır. 
c) Şerefiye sınırlı yararlı ömre sahip bir varlıktır ve itfanın uygulanması şerefiyedeki tükenmeyi göstermenin tek yoludur.

d) Şerefiyenin itfası, değer düşüklüğü testinin yükünü azaltarak, uygulanmasını daha kolay ve daha az maliyetli hale getirebilir. İtfa uygulaması, şerefiyenin defter değerinin azalmasına neden olmaktadır. Dolayısıyla, şerefiyenin defter değerinin yönetimin aşırı iyimserliği veya şerefiyenin değer düşüklüğü açısından test edilmemesi nedeniyle olduğundan yüksek gösterilebileceğine inanan paydaşların endişelerinin giderilmesine yardımcı olabileceği ve böylece finansal raporların doğru bir şekilde sunulacağı savunulmaktadır.

Şerefiyede itfanın yeniden uygulamaya konmamasını ve sadece değer düşüklüğü yaklaşımınının uygulamaya devam edilmesini savunan Kurul üyelerinin görüşleri ise aşağıda açıklanmaktadır:

a) Şerefiyede değer düşüklüğü zararının raporlanması (gecikmeli olsa bile), ihtiyaca uygun bilgi sağlamaktadır. Gecikmeli olsa bile, değer düşüklüğü zararının raporlanması, yatırımcıların daha erken bir tarihte bu zararların ortaya çıkmış olduğunu değerlendirmelerine ve yönetimin yatırımcılara hesap vermesine yardımcı olacağı savunulmaktadır.

b)Şerefiyenin faydalı ömrünün objektif bir şekilde tahmin edilmesine yönelik kural veya ilkelerin olmaması nedeniyle, hesaplanacak itfa payının yatırımcılara faydalı bilgi sağlamayabileceği, bu nedenle işletmelerin yönetim performans ölçütleri arasında yer alan faiz ve vergi öncesi kar (FVÖK) hesaplamasında amortisman ve itfa giderinin etkisinin yok edildiği savunulmaktadır. FVÖK hesaplamasında amortisman ve itfa giderinin etkisinin yok edilmesi sonucunda, şerefiyenin itfası, yönetimin birleşme kararına ilişkin olarak yatırımcılara hesap vermelerini sağlamakta kullanılamayacak ve performans değerlendirmelerinde ihmal edilmiş olacaktır.

Şerefiyenin faydalı ömrünün objektif bir şekilde tahmin edilememesi, şerefiyeden beklenen kalan ekonomik faydanın objektif bir şekilde tespitini de mümkün kılmamaktadır. $\mathrm{Bu}$ nedenle, şerefiyenin defter değerinden düşülecek olan itfa tutarı sağlıklı bir şekilde tespit edilemeyecek ve böylece itfa yoluyla şerefiyenin defter değerinin azaltılması, kalan faydanın gerçeğe uygun bir sunumu sağlanamayabilecektir (DP - 3.72-80). Ayrıca, itfa uygulmasının şerefiyenin defter değerinde azalışa neden olması, buna karşılık, geri kazanılabilir tutarın çoğunlukla defter değerinden yüksek bir tutarda kalması, değer düşüklüğü zararının muhasebeleştirilme olasılığını azaltabilmektedir. Şerefiyenin defter değerinde itfadan dolayı ortaya çıkan azalış, geri kazanılabilir tutarın yüksek olma ihtimalini arttıracaktır ki bu da yine korunma etkisinin varlığını ortaya çıkarabilmektedir (DP - 3.72-80).

c) Şerefiyede değer düşüklüğü testinin titiz bir şekilde yapılmadığına dair endişelerden dolayı veya sadece defter değerini azaltmış olmak için yeniden itfa uygulamasına geçilmesinin düşünülmemesi gerektiği, aksine, ekonominin değişen yapısı ve işletme içinde yaratılan ve kayda alınmayan maddi olmayan duran varlıkların değerinin artmasına bağlı olarak şerefiyenin değerinde de bir artış meydana geldiği savunulmaktadır.

d)İtfaya tabi tutulan şerefiyenin yatırımcılara sunulan bilgiyi önemli ölçüde iyileştireceği veya birleşmeden sonraki ilk birkaç yılda, değer düşüklüğü testinin maliyetini 
önemli ölçüde azaltacağı yönünde ikna edici bir delil bulunmadığı yönünde görüşler mevcuttur.

Kurul üyeleri tarafından şerefiyenin itfasının yeniden uygulanıp uygulanmayacağına ilişkin yapılan tartışmalar sonucunda, Kurul, ön görüş olarak, şerefiyede değer düşüklügü yaklaşımını uygulamaya devam etmeyi ve itfayı yeniden uygulamamayı benimsemiştir. İtfa uygulamasına geçişin, şerefiyenin muhasebeleştirilmesindeki karmaşıklığ 1 daha da arttırabileceği savunulmaktadır. Örneğin, şerefiyenin faydalı ömrünün tahmin edilmesi önemli düzeyde yargıda bulunulmasını ve şerefiyenin değer düşüklüğü testinde kullanılacak olan gelecekteki nakit akışlarının da aynı yargıya dayalı olarak tahmin edilmesini gerektirecektir (DP 3.83). Şerefiyenin yalnızca değer düşüklüğü testine tabi tutulması veya itfa edilmesi yönünde literatürde yapılan çalışmalarda da, şerefiyenin yalnızca değer düşüklüğü testine tabi tutulması sonucu elde edilen bilgilerin işletmenin ekonomik değerini daha doğru yansittığ yönünde bulgulara ulaşılmıştır (Chalmers, Godfrey ve Webster, 2011; Chen ve diğerleri, 2004; Bens ve diğerleri, 2007). Ferramosca ve Allegrini (2021) tarafından yapılan bir araştırmada, dünya genelindeki 352 finans müdürünün (CFO) şerefiyede sadece değer düşüklüğü mü yoksa itfa yönteminin mi kullanılmasının uygun olduğuna yönelik görüşlerini almak için bir anket uygulaması yapılmıştır. Anket sonuçlarına göre, katılanların yarıdan fazlası alternatif uygulamaların daha faydalı bilgi sağlayabileceğini belirtmiş olsalar da, yaklaşık üçte ikisi itfa uygulmasını tercih etmiştir. Sadece değer düşüklügü modelini tercih eden CFO'ların bu tercihlerinde kişisel, firma ve ülke özelliklerinin etkili olduğu tespit edilmiştir. Bu özellikler, CFO'ların değerleme yöntemine ilişkin bilgi ve tecrübe düzeyi, bağımsız denetçilerin rolü, işletmenin ortaklık yapısı ve muhasebe kültürü ve ülkedeki muhasebe uygulamalarının kural bazlı olup olmamasidır.

Kurul'un şerefiyenin raporlanması ile ilişkili olarak Tartışma Metninde yer alan diğer bir görüşü, birleşmeden sonraki performans hakkında finansal tablolarda ilave açıklamaların yapılması gerektiği yönündedir. Tartışma Metninin Açıklamalar kısmında da belirtildiği gibi, şerefiyenin sonraki dönemlerde raporlanmasında itfanın yeniden uygulanmaya konması veya sadece değer düşüklüğü yaklaşımının muhafaza edilmesi bir birleşmenin başarısı hakkında tek başına bilgi sağlamayacağı, ilave açıklamaların, yatırımcılara birleşmenin başarısı veya başarısızlığı hakkında daha doğrulayıcı bilgi sunacağı ifade edilmektedir. $\mathrm{Bu}$ çerçevede, Tartışma Metnine gelecek görüşlerin değerlendirilmesi sonucunda, sadece değer düşüklügü yaklaşımının benimsenmesi halinde, Kurul'un yapılmasını önerdiği ilave açıklamaların değer düşüklüğü testinin birleşmenin başarısı hakkında zamanında bir sinyal vermediği yönündeki endişeleri giderebileceği, diğer taraftan itfanın yeniden uygulanmaya başlanmasının benimsenmesi halinde, önerilen açıklamaların, değer düşüklüğü zararına ilişkin endişeleri gidermeye yardımcı olabileceği kanaatine varılmıştır.

\subsection{Maddi Olmayan Duran Varlıkların Şerefiyeden Ayrı Olarak Muhasebeleştirilmesi}

IFRS 3 ve IAS 38' kapsamında bir işletme birleşmesinde edinilen, tanımlanabilir nitelikte olan maddi olmayan duran varlıklar şerefiyeden ayrı olarak muhasebeleştirilmektedir.

Birleşmede edinilen maddi olmayan duran varlıkların şerefiyeden ayrı olarak muhasebeleştirilmesinin, işletmenin neyi satın aldığını açıklamaya yardımcı olduğu yönünde 
görüşler olsa da, bazı kesimler bu bilginin yararlı olup olmadığını sorgulamaktadırlar. Bunun nedeni ise, işletme içinde yaratılan benzer nitelikteki maddi olmayan duran varlıkların muhasebeleştirilmemesi ve bir kısım maddi olmayan duran varlıkların değerinin tespit edilmesinin zor olmasıdır. Birleşmede edinilen maddi olmayan duran varlıkların şerefiyeden ayrı olarak muhasebeleştirilmesine ilişkin bilginin yatırımcılara ne kadar yarar sağladığ 1 ve bu bilgiyi elde etme maliyetine ilişkin birbirinden farklı görüşler bulunmaktadır. $\mathrm{Bu}$ nedenle, IASB'nin görüşü, birleşmede edinilen maddi olmayan duran varlıkların şerefiyeden ayrı olarak muhasebeleştirilmesi uygulamasının devam etmesi gerektiği yönündedir.

\section{ARAŞTIRMANIN AMACI VE YÖNTEMI}

Araştırmanın amacı, şerefiyenin raporlanmasına yönelik uygulamaların BIST 50 endeksinde işlem gören işletmeler açısından incelenmesidir. $\mathrm{Bu}$ kapsamda, finansal tablolarında şerefiye kalemini raporlayan 24 işletmenin 2020 yılına ait finansal tabloları ve dipnotları incelenmiştir. Çalışmada, nitel araştırma yöntemlerinden biri olan doküman incelemesi gerçekleştirilmiştir. İnceleme sonunda işletmelerden elde edilen bulgular Tablo 2'de özetlenmiştir:

Tablo 2. BIST 50 Endeksinde İşlem Gören İşletmelerde Şerefiyenin Raporlanması

\begin{tabular}{|c|c|c|c|c|c|c|c|}
\hline \multirow{3}{*}{ Şirketler } & \multirow{2}{*}{$\begin{array}{c}\text { Duran } \\
\text { Varlıklar } \\
\text { İçindeki } \\
\text { Payı } \\
\end{array}$} & \multirow{3}{*}{$\begin{array}{c}\text { Toplam } \\
\text { Varlıklar } \\
\text { İçindeki } \\
\text { Payı } \\
\end{array}$} & \multicolumn{4}{|c|}{ Geri Kazanılabilir Tutar } & \multirow{4}{*}{$\begin{array}{c}\begin{array}{c}\text { Değer } \\
\text { Düşüklüğü }\end{array} \\
\\
\text { Yok }\end{array}$} \\
\hline & & & \multicolumn{3}{|c|}{ Tahmin } & Yöntem & \\
\hline & $\%$ & & $\begin{array}{c}\text { Projeksiyon } \\
\text { Yılı }\end{array}$ & $\begin{array}{c}\text { Büyüme Oranı } \\
(\%)\end{array}$ & $\begin{array}{c}\text { İskonto Oranı } \\
\text { (\%) }\end{array}$ & & \\
\hline SİSE & 1,6 & 0,83 & 5 & 2 & 8 & $\begin{array}{c}\text { Kullanım } \\
\text { Değeri }\end{array}$ & \\
\hline HEKTS & 12 & 3,4 & 5 & $\begin{array}{l}\text { Nihai Büyüme } \\
\text { Orany:5 } \\
\text { Bütçelenmiş } \\
\text { FVÖK Büyüme } \\
\text { Oranı: } 23\end{array}$ & 19 (Brüt) & $\begin{array}{l}\text { Satış Maliyeti } \\
\text { Düşülmüşs } \\
\text { Gerçeğe } \\
\text { Uygun Değer } \\
\text { (Gelir } \\
\text { Yaklaşmı) }\end{array}$ & Yok \\
\hline DOHOL & 1,9 & 1 & Bilgi yok & Bilgi yok & $\begin{array}{c}\text { Sesa Ambalaj: } \\
\text { 14,6 (TL } \\
\text { cinsinden) } \\
\text { Galata Wind: } \\
\text { 7,17 (ABD } \\
\text { Dolar1 } \\
\text { cinsinden) } \\
\end{array}$ & $\begin{array}{l}\text { Sesa Ambalaj } \\
\text { ve Galata } \\
\text { Wind Gerçeğe } \\
\text { Uygun Değer } \\
\text { (Gelir } \\
\text { Yaklaşmı) }\end{array}$ & Yok \\
\hline GUBRF & 3 & 1 & Bilgi yok & 4 & 14 & $\begin{array}{c}\text { Kullanım } \\
\text { Değeri }\end{array}$ & Yok \\
\hline IHGLM & 0 & 0 & Bilgi yok & 8 & 24 & $\begin{array}{c}\text { Kullanım } \\
\text { Değeri }\end{array}$ & $\begin{array}{c}\text { Önceki } \\
\text { Dönemde } \\
\text { Tamamı için } \\
\text { Karşll1k } \\
\text { Hesaplanmıştır } \\
\end{array}$ \\
\hline İPEKE & 1 & 0,1 & & - & & $\begin{array}{c}\text { Newmont } \\
\text { Altın ve } \\
\text { Mastra } \\
\text { Madencilik: } \\
\text { Satış Maliyeti } \\
\text { Düsülmüş } \\
\text { Gerçeğe } \\
\text { Uygun Değer } \\
\text { (Piyasa } \\
\text { Değeri) } \\
\end{array}$ & $\begin{array}{c}\text { Newmont Altın: } \\
\text { yok } \\
\text { Mastra } \\
\text { Madencilik:var }\end{array}$ \\
\hline KARDEMIR & 0,1 & 0,1 & & Bilgi yok & & & Yok \\
\hline
\end{tabular}




\begin{tabular}{|c|c|c|c|c|c|c|c|}
\hline KARSAN & 1 & 0,4 & \multicolumn{3}{|c|}{ Bilgi yok } & $\begin{array}{c}\text { Kullanım } \\
\text { Değeri }\end{array}$ & Yok \\
\hline KOÇ H & 1 & 0,5 & $\begin{array}{l}\text { Tüpraş: } 10 \\
\text { Defy Grup: } \\
5 \text { Dawlance } \\
\text { Grubu: } 5\end{array}$ & $\begin{array}{l}\text { Tüpraş: 2,1, } \\
\text { Defy: 5,3, } \\
\text { Dawlance: } 5\end{array}$ & $\begin{array}{c}\text { Tüpraş: 11, } \\
\text { Defy:13,9 } \\
\text { (vergi sonrası), } \\
\text { Dawlance:14,7 } \\
\text { (vergi sonrası) }\end{array}$ & $\begin{array}{c}\text { Tüpraş: } \\
\text { Gerçeğe } \\
\text { Uygun Değer } \\
\text { (Gelir } \\
\text { Yaklaşmı) } \\
\text { Defy, } \\
\text { Dawlance: } \\
\text { Kullanım } \\
\text { Değeri } \\
\text { Singer } \\
\text { Bangladesh: } \\
\text { Gerçeğe } \\
\text { Uygun Değer } \\
\text { (Piyasa } \\
\text { Değeri) }\end{array}$ & Yok \\
\hline \multirow{3}{*}{ Şirketler } & $\begin{array}{c}\text { Duran } \\
\text { Varlıklar } \\
\text { İçindeki } \\
\text { Payı }\end{array}$ & $\begin{array}{c}\text { Toplam } \\
\text { Varlıklar } \\
\text { İçindeki } \\
\text { Payı }\end{array}$ & \multicolumn{4}{|c|}{ Geri Kazanılabilir Tutar } & $\begin{array}{c}\text { Değer } \\
\text { Düşüklüğgü }\end{array}$ \\
\hline & & & \multicolumn{3}{|c|}{ Tahmin } & \multirow[b]{2}{*}{ Yöntem } & \\
\hline & \multicolumn{2}{|c|}{$\%$} & $\begin{array}{c}\text { Projeksiyon } \\
\text { Yılı }\end{array}$ & $\begin{array}{c}\text { Büyüime Oranı } \\
(\%)\end{array}$ & $\begin{array}{c}\text { İskonto Oranı } \\
(\%)\end{array}$ & & \\
\hline $\begin{array}{c}\text { KOZA } \\
\text { ANADOLU }\end{array}$ & 0,7 & 0,1 & \multicolumn{3}{|c|}{-} & $\begin{array}{c}\text { Newmont } \\
\text { Altın ve } \\
\text { Mastra } \\
\text { Madencilik: } \\
\text { Satış Maliyeti } \\
\text { Düsülmüş } \\
\text { Gerçeğe } \\
\text { Uygun Değer } \\
\text { (Piyasa } \\
\text { Değeri) }\end{array}$ & $\begin{array}{c}\text { Newmont Altın: } \\
\text { yok } \\
\text { Mastra } \\
\text { Madencilik:var }\end{array}$ \\
\hline SAHOL & 0,7 & 0,3 & \multicolumn{4}{|c|}{ Bilgi yok } & Yok \\
\hline TAV & 6 & 4 & $\begin{array}{c}\text { Havaş: } 25 \\
\text { TAV Tiflis: } \\
\text { 13, GIS } \\
\text { İspanya: } 7\end{array}$ & $\begin{array}{c}\text { Havaş: } 2 \text { TAV } \\
\text { Tiflis: - } \\
\text { GIS İspanya:2 }\end{array}$ & $\begin{array}{c}\text { Havaş: } 15,8 \text {, } \\
\text { TAV } \\
\text { Tiflis:21,5 } \\
\text { GIS İspanya:13 } \\
\text { (vergi öncesi) }\end{array}$ & $\begin{array}{l}\text { Gerçeğe } \\
\text { Uygun Değer } \\
\text { (Gelir ve } \\
\text { Piyasa } \\
\text { Yaklaşmı) }\end{array}$ & Yok \\
\hline TEKFN & 2 & 1 & \multicolumn{3}{|c|}{ Bilgi yok } & $\begin{array}{l}\text { Satış maliyeti } \\
\text { Düşülmüş } \\
\text { Gerçeğe } \\
\text { Uygun Değer } \\
\text { (Gelir } \\
\text { Yaklaşımı) }\end{array}$ & Yok \\
\hline ÜLKER & 11 & 2,8 & & 2,1 & 10,1 & $\begin{array}{l}\text { Satış maliyeti } \\
\text { Düşülmüş } \\
\text { Gerçeğe } \\
\text { Uygun Değer } \\
\text { (Gelir } \\
\text { Yaklaşımı) } \\
\end{array}$ & Yok \\
\hline KOZAL & 0,5 & 0,1 & \multicolumn{3}{|c|}{ - } & $\begin{array}{c}\text { Newmont } \\
\text { Altın ve } \\
\text { Mastra } \\
\text { Madencilik: } \\
\text { Satış Maliyeti } \\
\text { Düsülmüş } \\
\text { Gerçeğe } \\
\text { Uygun Değer } \\
\text { (Piyasa } \\
\text { Değeri) }\end{array}$ & $\begin{array}{c}\text { Newmont Altın: } \\
\text { yok } \\
\text { Mastra } \\
\text { Madencilik:var }\end{array}$ \\
\hline
\end{tabular}




\begin{tabular}{|c|c|c|c|c|c|c|c|}
\hline MİGROS & 28 & 14 & 5 & Bilgi yok & $\begin{array}{l}7,9 \text { (vergi } \\
\text { sonras1) }\end{array}$ & $\begin{array}{l}\text { Satış maliyeti } \\
\text { Düşülmüş } \\
\text { Gerçeğe } \\
\text { Uygun Değer } \\
\text { (Gelir } \\
\text { Yaklaşımı) } \\
\end{array}$ & Yok \\
\hline MLP & 1,6 & 0,8 & 5 & $\begin{array}{c}\text { KHB: - } \\
\text { Kuzey Grup } \\
\text { Şirketleri: } 10 \\
\text { Uşak, Tokat, } \\
\text { Batman, } \\
\text { Yükseliş, } \\
\text { Acarkent, Saray, } \\
\text { ve Elazı̆ } \\
\text { Hastaneleri:11 }\end{array}$ & $\begin{array}{c}\text { KHB ve Kuzey } \\
\text { Grup } \\
\text { Şirketleri: } 16,4 \\
\text { Yükseliş, } \\
\text { Acarkent, } \\
\text { Saray, Uşak, } \\
\text { Tokat, Batman } \\
\text { ve Elazığ } \\
\text { Hastaneleri.20 }\end{array}$ & $\begin{array}{l}\text { Satış Maliyeti } \\
\text { Düşülmüş } \\
\text { Gerçeğe } \\
\text { Uygun Değer } \\
\text { (Gelir } \\
\text { Yaklaşımı) }\end{array}$ & Yok \\
\hline THY & 0,05 & 0,04 & \multicolumn{3}{|c|}{ Bilgi yok } & Bilgi yok & Yok \\
\hline ŞOK & 13 & 7,4 & \multicolumn{3}{|c|}{ - } & $\begin{array}{c}\text { Gerçeğe } \\
\text { Uygun Değer } \\
\text { (Piyasa } \\
\text { Yaklașımı)* }\end{array}$ & Yok \\
\hline VESTL & 2 & 1 & \multicolumn{3}{|c|}{ - } & $\begin{array}{c}\text { Gerçeğe } \\
\text { Uygun } \\
\text { Değer** }\end{array}$ & Yok \\
\hline \multirow[t]{3}{*}{ Şirketler } & $\begin{array}{c}\text { Duran } \\
\text { Varlıklar } \\
\text { İçindeki } \\
\text { Payı } \\
\end{array}$ & $\begin{array}{c}\text { Toplam } \\
\text { Varlıklar } \\
\text { İçindeki } \\
\text { Payı } \\
\end{array}$ & \multicolumn{4}{|c|}{$\begin{array}{l}\text { Geri Kazanılabilir Tutar } \\
\text { Şirketler }\end{array}$} & $\begin{array}{l}\text { Değer } \\
\text { Düşüklüğ̈̈ }\end{array}$ \\
\hline & & & \multicolumn{3}{|c|}{ Tahmin } & \multirow[b]{2}{*}{ Yöntem } & \\
\hline & $\%$ & & $\begin{array}{c}\text { Projeksiyon } \\
\text { Yılı }\end{array}$ & $\begin{array}{l}\text { Büyüme Oranı } \\
(\%)\end{array}$ & $\begin{array}{l}\text { İskonto Oranı } \\
(\%)\end{array}$ & & $\%$ \\
\hline AEFES & 9 & 6,5 & 10 & \multicolumn{2}{|c|}{ Bilgi yok } & $\begin{array}{c}\text { Kullanım } \\
\text { Değeri }\end{array}$ & Yok \\
\hline ARCLK & 7 & 2 & $\begin{array}{l}\text { Defy ve } \\
\text { Dawlance } \\
\text { Grubu: } 5\end{array}$ & $\begin{array}{l}\text { Defy: } 5,3 \text {, } \\
\text { Dawlance: } 5\end{array}$ & $\begin{array}{c}\text { Defy:13,9 } \\
\text { (vergi sonras1), } \\
\text { Dawlance:14,7 } \\
\text { (vergi sonrasi) }\end{array}$ & $\begin{array}{c}\text { Defy ve } \\
\text { Dawlance: } \\
\text { Kullanım } \\
\text { Değeri } \\
\text { Singer } \\
\text { Bangladesh: } \\
\text { Gerçeğe } \\
\text { Uygun Değer } \\
\text { (Piyasa } \\
\text { Değeri) } \\
\end{array}$ & Yok \\
\hline TCELL & 0,13 & 0,07 & \multicolumn{5}{|c|}{$\begin{array}{l}\text { SSerefiye tutarı, finansal tablolar açısından önemlilik arz etmemesi nedeniyle değer } \\
\text { düşüklüğü testinin yapılmadığı açıklanmaktadır. }\end{array}$} \\
\hline TTKOM & 0,14 & 0,1 & 5 ve 7 & $\begin{array}{c}\text { TTnet:7 } \\
\text { TTMobil, } \\
\text { Innova, Sebit ve } \\
\text { Argela:10 TTint: } \\
\text { - }\end{array}$ & $\begin{array}{c}\text { TTnet ve } \\
\text { TTMobil:17 } \\
\text { Innova:20,3 } \\
\text { Argela:21,9 } \\
\text { TTint:9,6 } \\
\text { Sebit:21,5 } \\
\end{array}$ & $\begin{array}{l}\text { Kullanım } \\
\text { Değeri }\end{array}$ & Yok \\
\hline
\end{tabular}

*Gerçeğe Uygun Değer (GUD), "Piyasa Çarpanları Yaklaşımı - Benzer Şirketler Analizi" dikkate alınarak, GUD/Faiz Amortisman Vergi Öncesi Kar ("FAVÖK”) ve GUD/Hasılat çarpanlarının sırasıyla \%40 ve \%60 oranlarının ağırlıklı ortalamasıyla hesaplanmıștır.

**Bilanço tarihi itibarıyla geçerli ortalama işlem tutarları üzerinden gerçeğe uygun değer hesaplaması yapılmıştır.

\section{ARAŞTIRMA BULGULARININ DEĞERLENDIRILMESI}

Araştırma kapsamında incelenen işletmelerde şerefiyenin duran varlıklar ve toplam varlıklar içerisindeki payının büyüklüğüne göre sınıflandırılması aşağıdaki şekildedir: 
Tablo 3. Şerefiyenin Duran Varlıklar ve Toplam Varlıklar İçindeki Payı

\begin{tabular}{|c|c|c|c|c|}
\hline \multirow{3}{*}{ İşletme Sayısı } & \multicolumn{4}{|c|}{ Şerefiyenin Duran Varlıklar İçindeki Payı } \\
\cline { 2 - 5 } & \%1'e kadar & $\begin{array}{c}\text { \%1'den \%5'e } \\
\text { kadar }\end{array}$ & $\begin{array}{c}\text { \%5'ten \%10'a } \\
\text { kadar }\end{array}$ & \%10'dan büyük \\
\cline { 2 - 5 } & 10 & 8 & 3 & 3 \\
\cline { 2 - 5 } & \multicolumn{4}{|c|}{ Şerefiyenin Toplam Varlıklar İçindeki Payı } \\
\cline { 2 - 5 } & 13 & 8 & 2 & 1 \\
\hline
\end{tabular}

Tablo 3’te görüldüğ̈̈ gibi, incelenen işletmelerin büyük bir çoğunluğunda, şerefiyenin duran varlıklar ve toplam varlıklar içindeki payı \%5'e kadardır. Sadece, bir işletmede (Migros) şerefiyenin toplam varlıklar içindeki payı \%10'un üzerindedir. Şerefiyenin duran varlıklar içindeki payının \%10'un üzerinde olduğu işletme sayısı ise üçtür (Migros, Hektaş ve Ülker).

Tablo 4. Geri Kazanılabilir Değerin Hesaplanmasında Kullanılan Yöntem

\begin{tabular}{|c|c|c|c|c|}
\hline & \multicolumn{4}{|c|}{ Yöntem } \\
\hline & \multirow[b]{2}{*}{$\begin{array}{c}\text { Kullanım } \\
\text { Değeri }\end{array}$} & \multicolumn{3}{|c|}{$\begin{array}{c}\text { Satış Maliyeti Düşülmüş Gerçeğe Uygun Değer } \\
\text { Değerleme Yöntemleri }\end{array}$} \\
\hline & & $\begin{array}{c}\text { Gelir } \\
\text { Yaklaşımı }\end{array}$ & $\begin{array}{c}\text { Piyasa } \\
\text { Yaklaşımı }\end{array}$ & $\begin{array}{l}\text { Piyasa } \\
\text { Değeri }\end{array}$ \\
\hline İşletme Sayısı & 8 & 8 & 2 & 6 \\
\hline
\end{tabular}

IAS 36/TMS 36'ya göre, işletmelerin her y1l düzenli olarak şerefiyede değer düşüklüğü testini yapma zorunluluğu bulunmasından dolayı, araştırma kapsamında yer alan işletmelerin tamamının değer düşüklüğü testini yaptıkları görülmektedir. Şerefiyenin ait olduğu nakit yaratan birimin geri kazanılabilir tutarının tespitinde kullanım değeri yöntemini kullanan işletmelerin sayısı $8^{\prime}$ 'dir. Diğger taraftan, satış maliyeti düşülmüş gerçeğe uygun değer yöntemini kullanan işletmelerin sayısı ise 16'dır. Söz konusu işletmelerin 6'sının nakit yaratan birimlerin gerçeğe uygun değerini IFRS 13'te yer alan sadece gelir yaklaşımını kullanarak tespit ettikleri, bir işletmenin hem gelir yaklaşımını hem de piyasa yaklaşımını kullandığı (TAV), bir işletmenin, gerçeğe uygun değerin tespitinde sadece piyasa yaklaşımını (Şok), 4 işletmenin (İpeke, Koza Anadolu, Kozal, Vestl) ise, piyasa değerini kullandıkları görülmektedir. Bir işletmenin (Koç Holding), kullanım değeri, satış maliyeti düşülmüş gerçeğe uygun değer (gelir yaklaşımını) ve piyasa değerini kullandığı, bir işletmenin ise (Arçelik), iki bağlı ortaklığı için kullanım değer yöntemini, bir bağlı ortaklığı için piyasa değerini kullandığı tespit edilmiştir. İncelenen işletmelerden Turkcell, finansal tablo dipnotlarında, şerefiyede değer düşüklüğü testini, tutarın önemli düzeyde olmaması nedeniyle gerçekleştirmediğini açıklamıştır. THY'nın dipnotlarında şerefiyeye ilişkin değer düşüklüğü testinin yapılıp yapılmadığına yönelik bir bilgi sunulmamıştır, sadece şerefiye tutarının yıl içerisindeki bakiye değişimine (çevirim farkı) yer verilmiştir. İhlas Gayrimenkul Proje Geliştirme ve Ticaret A.Ş. ise, 2019 yılında şerefiye tutarının tamamı için değer düşüklüğü karşılığı ayırmış olması nedeniyle, 2020 dönemi başındaki bakiyeyi sıfır olarak raporlamıştır. Ancak, bu işletme bir önceki döneme ilişkin finansal tablo dipnotlarında değer düşüklüğü testi için kullanım değeri yöntemini kullandığını açıklamıştır. İki işletmenin ise (Kardemir ve 
Sahol), tahmin varsayımları ve yönteme ilişkin herhangi bir açıklama yapmadığı görülmektedir.

Syzdykova (2016), BIST 100 endeksinde işlem gören şirketlerden, 2014 y1lına ait finansal tablolarında şerefiye hesabı olan 39 işletmeden 18 'inin geri kazanılabilir değerin belirlenmesinde kullanım değeri yöntemini, 4'ünün ise, satış maliyeti düşülmüş gerçeğe uygun değer yöntemini kullandığ tespit edilmiştir. 17 tanesinin ise, geri kazanılabilir değerin belirlenmesinde hangi yöntem ve varsayımların kullanıldığına ilişkin bilgileri dipnotlarında açıklamadığı belirtilmiştir.

Ertan ve Gücenme (2013), BIST 50 endeksinde işlem gören ve finansal tablolarında şerefiye kalemi mevcut olan işletmelerin TMS 36 çerçevesinde şerefiyeye ilişkin değer düşüklüğü uygulamalarını 2011 yılına ait finansal tablolaraını inceleyerek, geri kazanılabilir tutarın hesaplanmasında 17 işletmenin kullanım değerini dikkate aldığını, sadece bir işletmenin satış maliyeti düşülmüş gerçeğe uygun değer yöntemini kullandığını, 4 işletmenin ise, geri kazanılabilir tutarın tespitinde hangi yöntemi kullandıklarını açıklamadıklarını tespit etmişlerdir.

Değer düşüklüğü testinde, geri kazanılabilir tutar hesaplanırken, kullanım değeri yöntemini uygulayan işletmelerin 6 tanesi nakit akışlarının tahmininde 5 yılı dikkate almakta, iki işletme 5 yılın üzerinde (10yıl-25yıl) bir tahminde bulunmaktadır. Büyüme oranı ve iskonto oranı varsayımlarında, birbirinden farklı oranların dikkate alındığı, bazı işletmelerin büyüme oranı olarak ekonomiyi, bazı işletmelerin ise, sektördeki büyümeyi baz aldığı görülmektedir. Bu konuya ilişkin olarak yapılan bir araştırmada; Carlin and Finch (2008b), işletmelerin finansal tablolarına ilişkin dipnot bilgilerinde, şerefiyenin dağıtıldığı nakit yaratan birimler için geri kazanılabilir tutarın hesaplanmasında iskonto oranının düşük, büyüme oranının ise yüksek tutulduğuna yönelik eğilimin olduğunu tespit etmişlerdir.

TMS 36 madde 55 ve Ek-A20'ye göre, iskonto oranının tahmin edilmesinde, vergi öncesi oranın kullanılması gerektiği, vergi sonrası esasa dayanması durumunda, söz konusu esas vergi öncesi oranı yansıtacak şekilde düzeltmeye tabi tutulacağı ifade edilmektedir. Kullanım değeri yöntemini uygulayan işletmelerden Koç Holding ve Arçelik hariç, tamamının vergi öncesi iskonto oranını kullandıkları tespit edilmiştir. Vergi sonrası iskonto oranını kullanan Koç Holding ve Arçelik, bu oranı düzeltmeye tabi tuttuğunu açıklamıştır.

İnceleme kapsamındaki işletmelerden şerefiye bakiyesi sıfır olan ve tutarının önemli düzeyde olmaması nedeniyle değer düşüklüğü testi yapmayan işletmeler çıkarıldığında kalan 22 işletme, değer düşüklüğü testi sonucunda değer düşüklüğü zararı olmadığını raporlamıştır.

Koç Holding, TAV ve Şok'un finansal tablolarında, şerefiyede değer düşüklüğü, değer düşüklüğü testinde kullanılan tahmin ve varsayımların gelecekte beklenen piyasa koşullarına oldukça duyarlı olması nedeniyle kilit denetim konusu olarak belirlenmiştir. Şok'un finansal tablolarında, şerefiyede değer düşüklüğünün kilit denetim konusu olarak belirlenmesinin bir diğer nedeni, şerefiye tutarının varlıklar içindeki payının tutarsal önemi olarak açıklanmaktadır. Şerefiyenin varlık toplamı içindeki payı dikkate alındığında, Şok ile benzer oranlara sahip olan Anadolu Efes ve Migros'da ise, şerefiyede değer düşüklüğünün kilit denetim konusu olarak belirlenmediği görülmektedir. 
İncelenen işletmelerin tamamında "Not 2 Konsolide Finansal Tabloların Sunumuna İlişkin Esaslar" başlığı altında TFRS 3 İşletme Birleşmeleri Standardında yer alan şerefiyenin tanımı, nasıl hesaplandığı, ölçümü ve finansal tablolarda raporlanmasına ilişkin açıklamalara benzer ifadelerin kullanıldığı görülmektedir. İşletmeler, şerefiyenin dönem başı ve dönem sonu bakiyelerinin değişimini gösteren karşılaştırmalı bilgileri dipnotlarda açıklamaktadır.

2020 yılı içinde, Hektaş, Doğan Şirketler Grubu Holding A.Ş., Hacı Ömer Sabancı Holding A.Ş. ve Tekfen Holding A.Ş. işletme birleşmesi gerçekleştirmiştir. Söz konusu işletmelerin konsolide finansal tablo dipnotlarında, TFRS 3 - B64'e göre açıklanması istenen bilgilerden sadece; edinilen işletmenin unvanı ve tanımı, birleşme tarihi, edinilen işletmedeki oy hakkına sahip özkaynak payı yüzdesi, transfer edilen bedelin birleşme tarihindeki toplam gerçeğe uygun değeri bilgilerine yer verilmiştir. Ayrıca, Doğan Şirketler Grubu, konsolide kar veya zarar tablosunda, iktisap tarihine en yakın finansal tablo tarihi olan 31 Ağustos 2020 tarihinden 31 Aralık 2020 tarihine kadar elde edilen satış gelirlerinde edinilen işletmenin payını açıklamış, edinilen işletmenin 1 Ocak 2020 tarihinden itibaren konsolidasyona dahil edilmiş olsaydı, 1 Ocak - 31 Aralık 2020 hesap dönemine ait konsolide kar veya zarar tablosunda ilave satış gelirinin ne kadar olacağı bilgisine de yer vermiştir. İşletmelerin yatırımcıların birleşmenin nedenini ve şerefiyenin ortaya çıkmasına neden olan faktörleri anlamalarını sağlayacak (sinerji gibi) birtakım önemli bilgileri ise açıklamadıkları görülmüştür.

\section{SONUÇ}

İşletme birleşmeleri sonucunda ortaya çıkan şerefiyenin ölçümü ve dipnot açıklamaları özellikle yatırımcılar açısından önemli olan kalemlerden biridir. Şerefiyenin raporlanmasına ilişkin ilkelerin yer aldığı IFRS 3 İşletme Birleşmeleri Standardına yöneltilen eleştiriler sonucu, Kurul 2015 yılında "Şerefiye ve Değer Düşüklüğü Araştırma Projesi”ni başlatmıştır ve bu Proje kapsamında Tartışma Metnini yayınlamıştır. Tartışma Metninde, ele alınan konular; Birleşmeye ilişkin bilgilerin dipnotlarda açıklanması, şerefiyede değer düşüklüğü testi - etkinliği ve maliyeti, şerefiyede itfanın yeniden uygulanıp uygulanmayacağının değerlendirilmesi ve maddi olmayan duran varlıkların şerefiyeden ayrı olarak muhasebeleştirilmesidir. Kurul, bu konularla ilgili olarak ön görüşünü de içeren tartışma sorularını paydaşlara yöneltmiş ve 2020 yılı sonuna kadar geri bildirimlerin iletilmesini istemiştir. IFRS 3'ün Açıklamalar kısmında yapılması düşünülen değişiklik, yatırımcılara birleşmeyi tam olarak anlamalarını sağlayıcı, yeterli düzeyde faydalı bilgi sunulmasına yöneliktir. Kurul'un bu konudaki ön görüşü, birleşmenin amacı, amaca ulaşılıp ulaşılmadığının analizi için gerekli ölçütler, sonraki raporlama dönemlerinde amaca hangi seviyede ulaşıldığına dair ilave açıklamaların yapılmasının faydalı olacağı yönünde olmuştur. Şerefiyede değer düşüklüğü testininin etkinliğine yönelik yapılan tartışmalarda, Kurul, nakit akış tahminlerdeki iyimser bakış açısı ve korunma (shielding) etkisinden dolayı, değer düşüklüğü testinin daha etkin hale getirilmesinin mümkün olamayacağını, ancak dipnot açıklamaları kısmında yapılacak ilavelerle etkinliğin arttırılabileceği önerisinde bulunmuştur. Şerefiyede değer düşüklügü testinin maliyetini azaltmak üzere tartışmaya açılan bir diğer konu ise, değer düşüklüğü zararının ortaya çıktığına dair bir gösterge olmadıkça nicel bir test yapma zorunluluğundan uzaklaşılması ve sadece gösterge ortaya çıktığında testin yapılması ve değer düşüklüğü ortaya çıktığı takdirde zararın raporlanmasıdır. Kurul, şerefiyede değer düşüklüğü yaklaşımını uygulamaya devam etmeyi ve itfayı yeniden uygulamamayı, edinilen 
işletmenin maddi olmayan duran varlıklarının şerefiyeden ayrı olarak gösterilmesine devam edilmesi gerektiğini de savunmuştur.

Araştırma bulgularına göre, incelenen işletmelerin işletme birleşmelerine ilişkin açıklamalarında, standartta yer alan bilgileri (şerefiyenin tanımı, hesaplanması, sonraki ölçüm ve raporlanması) aktardıkları, ancak Tartışma Metninde de dile getirilen hususlardan biri olan, "yatırımcıların birleşmenin nedenini ve şerefiyenin ortaya çıkmasına neden olan faktörleri anlamalarını sağlayacak (sinerji gibi) sağlayacak bazı bilgileri” sunmadıkları tespit edilmiştir. İncelenen işletmelerden sadece üçünde, şerefiyede değer düşüklüğü zararı muhasebeleştirilmiştir. Değer düşüklüğü testine ilişkin olarak, işletmelerin büyük bir çoğunluğunun dipnot bilgilerinde tahminleri açıkladıkları ve hangi yöntemi kullandıkları bilgisine de yer verilmiştir.

\section{KAYNAKLAR}

Bens, Daniel A. - Heltzer, Wendy - Segal, Benjamin, (2007), "The Information Content of Goodwill Impairments and The Adoption of SFAS 142”, WP, University of Arizona Eller College of Management, Arizona, USA.

Beatty, Anne - Weber, Joseph (2006), “Accounting Discretion in Fair Value Estimates: An Examination of SFAS 142 Goodwill Impairments”, Journal of Accounting Research, 44 (2), ss. 257-288.

Carlin, Tyrone M - Finch, Nigel. (2008b), "Goodwill Impairment Testing Under IFRS - A False Impossible Shore?”, Pacific Accounting Review, 23(3), ss.368-392.

Chen, Changling - Kohlbeck, Mark - Warfield, Terry (2004), “Goodwill Valuation Effects of The Initial Adoption of SFAS 142”, WP, Florida Atlantic University - School of Accounting, Florida, USA.

Chalmers, Keryn - Godfrey, Jayne M. - Webster, John (2011), "Does A Goodwill Impairment Regime Better Reflect The Underlying Economic Attributes Of Goodwill?”, Accounting \& Finance, 51 (3), ss.634-660.

Deloitte Annual Turkish MA Review, 2020.

Ertan, Yasemin - Gücenme Gençoğlu, Ümit (2013), "Şerefiyede Değer Düşüklüğü Testi: İMKB 50 Endeksindeki İşletmelerin Uygulamaları", Muhasebe Bilim Dünyası Dergisi, 2, ss.1-22.

Ferramosca, Silvia - Allegrini Marco (2021), "Impairment or amortization of goodwill? An analysis of CFO Perceptions of Goodwill Accounting”, European Management Journal, https://doi.org/10.1016/j.emj.2021.03.001

Glaum, Martin - Landsman, Wayne R. - Wyrwa, Sven, (2018), “Goodwill Impairment: The Effects of Public Enforcement and Monitoring by Institutional Investors", The Accounting Review, 93(6), ss. 149-180, 
Gu, Feng - Lev, Baruch, (2011), “Overpriced Shares, I11-Advised Acquisitions and Goodwill Impairment”, Accounting Review, 86 (6), ss.1995-2022.

IFRS Standards Discussion Paper, (2020/1), Business Combinations-Disclosures, Goodwill and Impairment, March.

IFRS Report and Feedback Statement, (2015), Post-implementation Review of IFRS 3 Business Combinations.

IFRS 3 Business Combinations https://www.iasplus.com/en/standards/ifrs/ifrs3

IAS 36 Impairment of Assets https://www.iasplus.com/en/standards/ias/ias36

Ivanov, Aleksey - Generalova, Natalia - Sokolova, Natalia - Popova, Ekaterina Timoshenko, Eugeny (2018), Bad Synergy: Critical Analysis of a Combined Approach To Subsequent Goodwill Impairment (Amortization And Impairment Testing)”, Advances in Economics, Business and Management Research, 104, ss.258-265

Ramanna, Karthik - Watts, Ross, L. (2012), “Evidence on the Use of Unverifiable Estimates in Required Goodwill Impairment”, Review of Accounting Studies, 17 (4), ss.749780 .

Syzdykova, Aziza (2016), “Türkiye'de Tfrs'ye Göre Şerefiye Değer Düşüklüğü Testi: Bist 100 Şirketleri Tarafindan Kullanılan İskonto Oranlarının Analizi”, Gazi İktisat ve İşletme Dergisi, ss.23-40.

TFRS 3 İşletme Birleşmeleri 15/01/2019 tarih ve 30656 sayılı Resmi Gazete

TMS 36 Varlıklarda Değer Düşüklüğü 18/03/2006 tarih ve 26112 sayılı Resmi Gazete 
